Jurnal Kesmas Asclepius

Volume 1, Nomor 2, Desember 2019

e-ISSN: 2684-8287

p-ISSN: 2656-8926

DOI: https://doi.org/10.31539/jka.v1i2.578

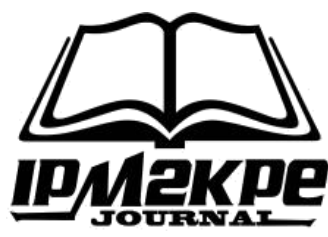

\title{
HUBUNGAN PENGETAHUAN DAN PENDIDIKAN IBU TERHADAP STATUS GIZI BALITA
}

\author{
Nurmaliza ${ }^{1}$, Sara Herlina ${ }^{2}$ \\ Universitas Abdurrab ${ }^{1,2}$ \\ nurmaliza@univrab.ac.id ${ }^{1}$
}

\begin{abstract}
ABSTRAK
Penelitian ini bertujuan untuk mengetahui hubungan pengetahuan dan pendidikan terhadap status gizi balita di Kecamatan Rumbai Pesisir Kota Pekanbaru. Penelitian ini merupakan penelitian kuantitatif analitik dengan pendekatan cross sectional. Hasil penelitian berdasarkan uji chi square diperolah nilai Pvalue $<0,05(<0,006<0,05)$ dan $(<0,034<0,05)$. Simpulan, ada hubungan antara pengetahuan dan pendidikan terhadap status gizi balita.
\end{abstract}

Kata Kunci: Balita, Pendidikan, Pengetahuan, Status Gizi

ABSTRACT

This study aims to determine the relationship between knowledge and education on the nutritional status of children under five in the Rumbai Pesisir District, Pekanbaru City. This research is a quantitative analytic study with a cross sectional approach. The results of the study based on the chi square test obtained the value of Pvalue $<0.05$ $(<0.006<0.05)$ and $(<0.034<0.05)$. In conclusion, there is a relationship between knowledge and education on the nutritional status of children under five.

Keywords: Toddler, Education, Knowledge, Nutritional Status

\section{PENDAHULUAN}

Golden Age berada pada masa kanak-kanak antara usia 1-6 tahun, usia ini merupakan masa yang sangat penting bagi pertumbuhan dan perkembangan individu. Perkembangan merupakan suatu proses bertambahnya struktur, fungsi, dan kemampuan manusia yang lebih kompleks dalam pola yang teratur, sebagai hasil dari proses pematangan (Sulistyawati, 2015). Sama seperti pernyataan dari (Soetjiningsih, 2015) yang menyatakan bahwa masa lima tahun pertama kehidupan merupakan masa yang sangat peka terhadap lingkungan dan masa ini berlangsung sangat pendek dan tidak bisa diulang kembali, masa ini sering juga disebut masa keemasan (Golden Period), jendela kesempatan (window of opportunity) dan masa kritis (Rahardjo et al., 2019).

Masa kanak-kanak memberi pengaruh yang besar pada individu dalam tahapan perkembangan selanjutnya. Anak toodler adalah anak yang berusia 1-3 tahun, yang pada umumnya kelompok anak tersebut sudah belajar percaya pada orang lain, mulai cepat meniru dan mengembangkan kemandirian membuka dan memakai baju, berjalan, mengambil, makan sendiri dan ke toilet mulai terbentuk kontrol diri. Jika perkembangan kemandirian toodler tidak didukung oleh orangtua, maka rerata anak akan memiliki kepribadian yang ragu-ragu, dan jika anak dibuat merasa buruk pada saat kegiatan 
stimulasi ia melakukan kegagalan, maka anak akan menjadi pemalu dan pendiam (Lestari \& Hati, 2016; Padila et al., 2019).

Perkembangan anak yang baik memerlukan stimulasi yang baik dari orangtua. Orangtua pun wajib mengetahui berbagai aspek perkembangan yang dialami oleh anak pada berbagai rentang usia. Orangtua sebaiknya juga penting mengetahui dan memahami bagaimana pemeriksaan dan stimulasi dini tumbuh kembang pada anak mereka, sehingga setiap keterlambatan yang terjadi pada anak dapat di deteksi dan di stimulasi dengan cepat (Padila et al., 2019).

Kualitas generasi penerus bangsa tergantung dari kualitas tumbuh kembang anak, terutama usia toodler (1-3) tahun, dimana anak menunjukkan perkembangan otak yang sangat signifikan, keluarga harus mengupayakan agar anaknya dapat bertumbuh dan berkembang secara optimal untuk mengindari tumbuh kembang yang abnormal, meragukan ataupun menyimpang. Penyimpangan tumbuh kembang harus dideteksi (ditemukan) sejak dini, terutama sebelum berumur 3 tahun, supaya dapat segera di intervensi (diperbaiki), bila deteksi terlambat, maka penanganan terlambat, sehingga penyimpangan sukar untuk diperbaiki (Betz et al., 2009). Masa anak dianggap sebagai fase yang penting karena akan menentukan kualitas kesehatan, kesejahteraan, pembelajaran, dan perilaku dimasa yang akan dating serta masa depan masyarakat tergantung pada anak-anak yang mampu mencapai pertumbuhan dan perkembangan yang optimal (WHO, 2015).

Hasil Riskesdas dari tahun 2007 ke tahun 2013 menunjukkan fakta yang memprihatinkan dimana underweight meningkat dari $18,4 \%$ menjadi $19,6 \%$, stunting juga meningkat dari $36,8 \%$ menjadi $37,2 \%$, sementara wasting (kurus) menurun dari 13,6\% menjadi 12,1\% (Kemenkes, 2015). Berdasarkan petunjuk teknik pemantauan status gizi (PSG) anak balita tahun 1999, klasifikasi status gizi dibedakan menjadi 5 yaitu: gizi buruk, gizi kurang, gizi sedang, gizi baik dan gizi lebih. Baku WHO-NCHS (World Health Organization- National Centre for Health Statics) digunakan sebagai baku antropometri Indonesia (Depkes RI, 2011).

Prevalensi gizi buruk balita di Provinsi Riau pada tahun 2015 (1,03) mengalami penurunan dibanding tahun sebelumnya $(1,28 \%)$. Prevalensi gizi buruk balita tahun 2015 berada dibawah target yang telah ditetapkan yaitu 1,5\%. Sedangkan prevalensi gizi kurang ternyata mengalami kenaikan dari tahun 2014 sebesar 6,6\% menjadi 7,7\% pada tahun 2015. Akan tetapi, prevalensi gizi kurang tersebut masih berada dibawah target propinsi pada tahun 2015 yaitu sebesar 8,8\% (Dinas Kesehatan Riau, 2015).

Status gizi anak balita salah satunya dipengaruhi oleh faktor kondisi sosial ekonomi, antara lain pendidikan ibu, pekerjaan ibu, jumlah anak, pengetahuan dan pola asuh ibu serta kondisi ekonomi orang tua secara keseluruhan. Status gizi adalah keadaan tubuh sebagai akibat dari pemakaian, penyerapan, dan penggunaan makanan. Pengertian lain menyebutkan bahwa status gizi merupakan ekspresi dari keadaan keseimbangan dalam bentuk variabel tertentu, atau perwujudan dari status tubuh yang berhubungan dengan gizi dalam bentuk variabel tertentu (Supariasa et al., 2012). Rencana pembangunan jangka menengah nasional 2010-2014, perbaikan status gizi masyarakat merupakan salah satu prioritas dengan menurunkan prevalensi balita gizi kurang (underweight) menjadi 15\% dan prevalensi balita pendek (stunting) menjadi 32\% pada tahun 2014.

Penyebab timbulnya gizi kurang dapat dipengaruhi beberapa faktor diantaranya adalah faktor internal dan eksternal. Faktor internal yaitu asupan makanan dan penyakit infeksi. Faktor eksternal yaitu pendidikan orangtua, jenis pekerjaan, pendapatan 
orangtua, pengetahuan ibu ketersediaan pangan dan pola konsumsi pangan (Adriani \& Wiratmadi, 2014). Kurangnya pengetahuan gizi dan kesehatan orangtua, khususnya ibu merupakan salah satu penyebab kekurangan gizi pada anak balita. Pengetahuan ibu tentang gizi adalah yang diketahui ibu tentang pangan sehat, pangan sehat untuk golongan usia tertentu dan cara ibu memilih, mengolah dan menyiapkan pangan dengan benar. Pengetahuan gizi ibu yang kurang akan berpengaruh terhadap status gizi balitanya dan akan sukar memilih makanan yang bergizi untuk anaknya dan keluarganya. Pengetahuan tentang gizi dan pangan yang harus dikonsumsi agar tetap sehat merupakan faktor penentu kesehatan seseorang, tingkat pengetahuan ibu tentang gizi juga berperan dalam besaran masalah gizi di Indonesia (Notoatmodjo, 2010).

Anak balita merupakan salah satu kelompok usia yang mendapatkan prioritas utama oleh pemerintah dalam hal upaya perbaikan gizi karena kelompok anak pada usia tersebut masih sangat memerlukan gizi untuk pertumbuhan dan perkembangan. Balita yang kurang gizi mempunyai risiko meninggal lebih tinggi dibandingkan balita yang tidak kurang gizi (WHO, 2015). Masa balita menjadi lebih penting karena merupakan masa yang kritis dalam upaya menciptakan sumber daya manusia yang berkualitas di masa yang akan datang. Terlebih lagi triwulan kedua dan ketiga masa kehamilan dan dua tahun pertama pasca kelahiran merupakan masa emas (golden periode) dimana selsel otak sedang mengalami pertumbuhan dan perkembangan yang optimal. Anak di bawah lima tahun (Balita) merupakan masa terbentuknya dasar kepribadian manusia, kemampuan penginderaan, berpikir, keterampilan berbahasa dan berbicara, bertingkah laku sosial dan lain sebagainya. Anak balita merupakan kelompok tersendiri yang dalam perkembangan dan pertumbuhannya memerlukan perhatian yang lebih khusus. Apabila perkembangan dan pertumbuhan pada masa balita ini mengalami gangguan, hal ini akan berakibat terganggunya persiapan terhadap pembentukan anak yang berkualitas (Lubis, 2004).

Adanya gangguan kesehatan akan membawa dampak terhadap laju tumbuh kembang tubuh anak sedangkan salah satu faktor yang dapat menentukan daya tahan tubuh seseorang anak adalah keadaan gizinya (Soetjiningsih, 2014). Upaya mencapai status gizi anak balita yang baik tidak terlepas dari peran orang tua khususnya ibu sebagai pengasuh karena ibu sebagai seorang yang bertanggung jawab dalam penyelenggaraan makan keluarga termasuk untuk anak balita sangat penting. Hal ini dapat tercermin di dalam pola pemberian makanan balita yang di terapkan atau di praktekkan ibukepada anak balita yang diwujudkan dalam sikap dan perilaku. Anak merupakan konsumenpasif, artinya anak menerima makanan dari apa yang disediakan ibunya (Proverawati, 2009).

Asupan gizi yang baik pada anak sering tidak bisa dipenuhi seorang anak karena disebabkan beberapa faktor. Termasuk diantaranya adalah tingkat pendidikan ibu, pengetahuan ibu tentang gizi dan kesehatan, kondisi social ekonomi keluarga, ketersediaan bahan pangan, serta hubungan emosional anggota keluarga yang lain yang tercermin dalam suatu kebiasaan. Adanya faktor-faktor tersebut menjadikan perlu adanya suatu perhatian dalam memberikan makanan kepada anak karena perilaku dan sikap yang terpola 3 dalam suatu kebiasaan memberi makan kepada anak dapat mempengaruhi asupan zat-zat gizi untuk anak (Supariasa et al., 2012).

Hasil penelitian Munawaroh (2015) menyatakan bahwa ibu yang memberikan pola asuh baik dan status gizi kurus ada sebanyak 29 (90,6\%), sedangkan ibu yang mempunyai pola asuh kurang baik, ada $11(47,9 \%)$ balita kurus. Hasil uji statistik diperoleh nilai pvalue 0,012 maka dapat disimpulkan ada hubungan pola asuh dengan 
status gizi balita. Menurut penelitian Rakhmawati (2014) bahwa terdapat kecenderungan pola asuhdenganstatus gizi balita. Dengan kata lain, jika pola asuh anak dalam keluarga baik tentunya tingkat konsumsi pangan anak juga akan semakin baik dan akhirnya akan mempengaruhi keadaan gizi anak. Dari hasil penelitian menunjukkan $86,15 \%$ ibu mempunyai pengetahuan baik, 76,92\% ibu mempunyai sikap kurang dan $73,95 \%$ ibu mempunyai perilaku kurang. Analisis data menunjukan adanya hubungan antara pengetahuan terhadap perilaku ibu dalam pemberian makanan untuk anak $(p=0,003)$ dan ada hubungan antara sikap dan perilaku ibudalam pemberian makanan untuk anak $(p=0,04)$.

Pola asuh orang tua dalam memberikan makan kepada balita merupakan upanya untuk mengurangi prevalensi gizi kurang baik di Indonesia maupun di Provinsi Riau. Maka untuk itu perlu dilakukan penelitian tentang pola asuh dalam pemberian makanan terhadap status gizi balita.

\section{METODE PENELITIAN}

Penelitian ini bersifat kuantitatif analitik dengan jenis desain cross-sectional study. Penelitian ini dilakukan di Kecamatan Rumbai Pesisir Kota Pekanbaru Tahun 2017. Sampel dalam penelitian ini adalah sebagian ibu yang mempunyai balita sebanyak 70 orang. Teknik pengambilan sampel yang digunakan adalah purposive sampling.

Jenis data yang digunakan adalah data primer yang diperoleh langsung dari responden dengan cara menyebarkan kuesioner. Teknik pengumpulan data dalam penelitian ini adalah dengan cara menyebarkan kuesioner kepada responden dan observasi status gizi balita. Analisa yang digunakan adalah univariat dan bivariat dengan uji Chi-square Data diolah dengan cara editing, coding, processing, cleaning dan tabulating.

\section{HASIL PENELITIAN AnalisaUnivariat}

Tabel. 1

Distribusi Responden

\begin{tabular}{cccc}
\hline No & Variabel & $\mathrm{n}$ & $\%$ \\
\hline 1 & Pengetahuan & & \\
& Kurang & 26 & 37,1 \\
& Baik & 44 & 62,9 \\
$2 . \quad$ Pendidikan & & \\
& Rendah & 29 & 41,4 \\
& Tinggi & 41 & 58,6 \\
& Variabel Dependen & & \\
& Gizi Balita & & 37,1 \\
& Kurang & 26 & 62.9 \\
\hline & Baik & 44 &
\end{tabular}

Berdasarkan analisis univariat pada tabel 1 menunjukkan bahwa mayoritas ibu memiliki pengetahuan baik yaitu sebanyak 44 orang $(62,9 \%)$, berpendidikan tinggi sebanyak 58,6\%, mayoritas ibu memiliki status gizi balita baik sebanyak 62,9\%. 


\section{AnalisaBivariat}

Tabel. 2

Hubungan Pengetahuan dan Pendidikan Ibu terhadap Status Gizi Balita

\begin{tabular}{lccccc}
\hline \multirow{2}{*}{ Variabel } & \multicolumn{2}{c}{ Kategori Status Gizi Balita } & & \\
& & Kurang & & Baik & P Value \\
& $\mathrm{n}$ & $\%$ & $\mathrm{n}$ & $\%$ & \\
\hline Pengetahuan & 15 & $(57,7)$ & 11 & $(16,3)$ & 0,006 \\
Kurang & 11 & $(25,0)$ & 33 & $(75,0)$ & \\
Baik & 15 & $(51,7)$ & 14 & $(48,3)$ & 0,034 \\
Pendidikan & 11 & $(26,8)$ & 30 & $(73,2)$ & \\
Tinggi & & & & & \\
\hline
\end{tabular}

Tabel 2 menunjukkan, dari hasil penelitian dapat dilihat bahwa ibu yang berpendidikan tinggi memiliki status gizi baik yaitu $73,2 \%$, sedangkan ibu yang memiliki pengetahuan baik memiliki status gizi balita baik yaitu $75,0 \%$.

\section{PEMBAHASAN}

Dari hasil uji chi-square menunjukkan bahwa ada hubungan antara pengetahuan dan pendidikan ibu terhadap status gizi balita. Berdasarkan hasil penelitian diperoleh bahwa ibu yang berpendidikan tinggi memiliki status gizi balita baik yaitu 73,2 \%, sedangkan ibu yang berpenegtahuan baik memiliki status gizi balita baik yaitu 75,0 \% . Oleh karena itu ibu yang mempunyai pengetahuan kurang akan beresiko 4 kali mempunyai balita dengan status gizi kurang dibandingkan dengan ibu yang memiliki pengetahuan baik terhadap status gizi balita, sedangkan ibu yang berpendidikan rendah akan lebih beresiko 3 kali mempunyai balita dengan status gizi kurang dibandingkan dengan ibu yang berpendidikan tinggi terhadap status gizi balita.

Faktor yang dapat mempengaruhi status gizi pada balita adalah asupan makanan pada anak dan penyakit infeksi yang merupakan penyebab langsung, sedangkan penyebab tidak langsungnya adalah persediaan makanan dirumah, pengetahuan, pola pengasuhan anak, pelayanan kesehatan dan kesehatan lingkungan serta kemiskinan. Pengetahuan dalam penelitian ini adalah pemahaman ibu balita tentang kebutuhan gizi balita meliputi pengertian zat gizi, macam-macam, manfaat dan tanda kekurangan gizi. Secara proporsi menunjukkan ibu berpengetahuan baik mayoritas memiliki balita dengan gizi baik yaitu $83,01 \%$ lebih banyak dibandingkan ibu dengan pengetahuan kurang yaitu 54,76\% (Susilowati \& Himawati, 2017).

Teori ini juga didukung oleh Adriani \& Wiratmadi (2014) yang menyatakan bahwa penyebab timbulnya gizi kurang dapat dipengaruhi oleh beberapa faktor diantaranya adalah faktor internal dan eksternal. Faktor internal yaitu asupan makanan dan penyakit infeksi. Faktor eksternal yaitu pendidikan orangtua, jenis pekerjaan, pendapatan orangtua, pengetahuan ibu ketersediaan pangan dan pola konsumsi pangan.

Kurangnya pengetahuan gizi dan kesehatan orangtua, khususnya ibu merupakan salah satu penyebab kekurangan gizi pada anak balita. Pengetahuan ibu tentang gizi adalah yang diketahui ibu tentang pangan sehat, pangan sehat untuk golongan usia tertentu dan cara ibu memilih, mengolah dan menyiapkan pangan dengan benar. Pengetahuan gizi ibu yang kurang akan berpengaruh terhadap status gizi balitanya dan akan sukar memilih makanan yang bergizi untuk anaknya dan keluarganya. 
Pengetahuan tentang gizi dan pangan yang harus dikonsumsi agar tetap sehat merupakan faktor penentu kesehatan seseorang, tingkat pengetahuan ibu tentang gizi juga berperan dalam besaran masalah gizi di Indonesia (Notoatmodjo, 2010).

Penelitian yang dilakukan Yuli (2016) menunjukkan bahwa jumlah balita yang mempunyai ibu berpendidikan tinggi adalah 112 orang, lebih tinggi daripada balita yang mempunyai ibu berpendidikan rendah yaitu 102 orang. Proporsi gizi kurang pada balita yang mempunyai ibu berpendidikan rendah jauh lebih tinggi daripada yang mempunyai ibu berpendidikan tinggi yaitu 17,9\% dibanding 7,8\%. Penelitian yang dilakukan Puspasari \& Andriani (2017) menunjukkan bahwa sebagian besar ibu balita memiliki pengetahuan tentang gizi yang baik dengan status gizi balita normal $(81,8 \%)$ dan yang memiliki pengetahuan kurang dengan status gizi balita tidak normal $(92,9 \%)$.

Penelitian ini sejalan dengan penelitian yang dilakukan Wati \& Subagyo (2018) yang menyatakan bahwa ada hubungan yang signifikan antara tingkat pendidikan ibu dengan status gizi anak balita. Penelitian ini juga menunjukkan bahwa sebagian besar anak balita yang memiliki status gizi tidak normal ibunya berpendidikan rendah (50\%). Hal ini menunjukkan bahwa peran seorang ibu sangat penting dalam kesehatan dan pertumbuhan anaknya. Seorang anak dari ibu yang mempunyai latar belakang berpendidikan tinggi maka akan mendapatkan kesempatan hidup serta tumbuh dan mudah menerima wawasan yang lebih luas mengenai gizi (Supariasa, 2012). Anak dengan ibu yang mempunyai pendidikan rendah memiliki angka mortalitas yang lebih tinggi daripada anak dengan ibu berpendidikan tinggi. Rendahnya tingkat pendidikan ibu menyebabkan berbagai keterbatasan dalam menangani masalah gizi dan keluarga serta anak balitanya (Herman, 2009).

Penelitian ini sejalan dengan penelitian yang dilakukan Jannah \& Maesaroh (2014) yang menyatakan adanya hubungan antara tingkat pendidikan ibu dengan status gizi balita di posyandu bangunsari semin gunung kidul. Penelitian ini juga sejalan dengan penelitian yang dilakukan Ranityas et al., (2016) yang menyatakan adanya hubungan tingkat pendidikan ibu dengan status gizi balita di puskesmas pleret.

Penelitian yang dilakukan Susilowati \& Himawati (2017) tentang hubungan tingkat pengetahuan ibu dengan status gizi balita di wilayah kerja puskesmas Gajah 1 Demak menunjukkan bahwa ada hubungan yang signifikan antara tingkat pengetahuan ibu tentang gizi balita dengan status gizi balita.

Hasil penelitian ini sejalan dengan penelitian yang dilakukan oleh Susanti et al., (2014) yang menyatakan adanya hubungan antara pengetahuan ibu tentang gizi anak dengan status gizi anak usia 1-3 tahun di wilayah kerja puskesmas rejosari kelurahan sail kecamatan tenayan raya kota pekanbaru. Penelitian ini juga sejalan dengan penelitian Kurniawati (2010) yang menyatakan adanya hubungan antara tingkat pengetahuan ibu tentang gizi dengan status gizi balita di kelurahan baledono kecamatan purworejo kabupaten purworejo.

Hasil diatas menunjukkan bahwa sebagian besar ibu yang berpengetahuan kurang mempunyai status gizi anak balita yang tidak normal sebanyak 11 responden (47,8\%). Pengetahuan ibu sangat penting peranannya dalam menentukan asupan makanan karena tingkat pengetahuan gizi seseorang berpengaruh terhadap perilaku dalam memilih makanan yang akan berdampak pada asupan gizi anaknya. pengetahuan ibu yang berbeda dapat mempengaruhi status gizi anak nya. Pengetahuan ibu yang baik tentang gizi akan mempermudah ibu dalam mengasuh anak terutama memperhatikan asupan makanan anak sehingga status gizi anaknya baik. Sedangkan ibu yang mempunyai pengetahuan kurang tentang gizi dapat mengakibatkan berkurangnya kemampuan untuk 
menerapkan informasi dalam kehidupan sehari-hari yang merupakan salah satu penyebab terjadinya gangguan gizi (Notoatmodjo, 2010).

Akan tetapi penelitian yang dilakukan oleh Burhani et al., (2016) menyatakan bahwa tidak ada hubungan antara tingkat pengetahuan ibu dan tingkat ekonomi keluarga dengan status gizi balita. Hasil penelitian serupa yang dilakukan oleh Morani (2008) pada balita di Kecamatan Kotaruopan Kabupaten Mandailing Natal, juga mengatakan bahwa tidak terdapat hubungan yang bermakna antara tingkat pengetahuan ibu terhadap status gizi balita. Hal ini disebabkan karena banyak sekali yang bisa mempengaruhi gizi balita, seperti ketersediaan pangan, pola konsumsi, penyakit infeksi, peran serta tokoh masyarakat, dan aktivitas ibu. Menurut Meikawati \& Wikana (2008) pola asuh ibu dan keluarga terhadap balita dan jumlah anggota keluarga juga mempengaruhi status gizi balita. Adanya perkembangan teknologi saat ini ibu dapat dengan mudah mengetahui informasi dari berbagai media, sehingga ibu dapat meningkatkan pengetahuannya (Astuti, 2012).

Status gizi adalah ekspresi dari keadaan keseimbangan dalam bentuk variabel tertentu atau perwujudan dari nutriture dalam bentuk variabel tertentu (Supariasa et al., 2012). Penilaian status gizi dapat dibagi menjadi empat penilaian yaitu ; antropometri, klinis, biokimia dan biofisik. Berdasarkan buku Harvard status gizi dapat dibagi menjadi empat yaitu : 1) Gizi lebih untuk over weight, termasuk kegemukan dan obesitas, 2) Gizi baik untuk well nourished,3) Gizi kurang untuk under weight yang mencakup mild dan moderate PCM (Protein Calorie Malnutrition), 4) Gizi buruk untuk severe PCM, termasuk marasmus, marasmik kwasiorkor dan kwashiorkor.

Masa balita adalah masa partumbuhan sehingga memerlukan gizi yang baik. Kebutuhan zat-zat gizi utama yang meliputi 5 komponen dasar, yakni hidrat arang, protein, lemak, mineral dan vitamin (termasuk air dalam yang cukup). Kebutuhan gizi pada balita diantaranya energi, protein, lemak, air, hidrat arang dan vitamin mineral (Merryana, 2012).

Perkembangan anak yang baik memerlukan stimulasi yang baik dari orangtua. Orangtua pun wajib mengetahui berbagai aspek perkembangan yang dialami oleh anak pada berbagai rentang usia. Orangtua sebaiknya juga penting mengetahui dan memahami bagaimana pemeriksaan dan stimulasi dini tumbuh kembang pada anak mereka, sehingga setiap keterlambatan yang terjadi pada anak dapat di deteksi dan di stimulasi dengan cepat (Padila et al., 2019).

Dalam masa pengasuhan, lingkungan pertama yang berhubungan dengan anak adalah orang tuanya. Anak tumbuh dan berkembang di bawah asuhan dan perawatan orang tua oleh karena itu orang tua merupakan dasar pertama bagi pembentukan pribadi anak. Melalui orang tua, anak beradaptasi dengan lingkungannya untuk mengenal dunia sekitarnya serta pola pergaulan hidup yang berlaku dilingkungannya (Soetjiningsih, 2014). Berdasarkan hasil penelitian sebagian besar pendidikan ibu tinggi terhadap status gizi balita sebanyak orang 41 orang $(41,0 \%)$, hal ini dilatar belakangi oleh pendidikan ibu yang sebagian besar berpendidikan tinggi.

Sesuai dengan yang dikemukakan oleh Soetijiningsih (2014) bahwa pendidikan orang tua merupakan salah satu faktor yang penting dalam status gizi. Karena dengan pendidikan yang baik, maka orang tua dapat menerima segala informasi dari luar tentang cara pengasuhan anak yang baik terutama bagai mana ibu memberikan makanan kepada anak, bagaimana menjaga kesehatan anak, pendidikannya, dan sebagainya. Sehingga makin banyak pengetahuan yang dimiliki dan perilaku yang diharapkan akan muncul pola asuh yang baik. 
Tingkat pengetahuan ibu tentang gizi balita sangat mempengaruhi keadaan gizi balita tersebut karena ibu adalah seorang yang paling besar keterikatannya terhadap anak. Kebersamaan ibu dengan anaknya lebih besar dibandingkan dengan anggota keluarga yang lain sehingga lebih mengerti segala kebutuhan yang dibutuhkan anak. Pengetahuan yang dimiliki ibu menjadi kunci utama kebutuhan gizi balita terpenuhi. Pengetahuan yang didasari dengan pemahaman yang baik dapat menumbuhkan perilaku baru yang baik pula. Pengetahuan ibu tentang kebutuhan gizi yang dipahami dengan baik akan diiringi dengan perilaku pemberian makanan bergizi bagi balita. Pengetahuan bisa didapat dari informasi berbagai media seperti TV, radio atau surat kabar seperti halnya dalam penelitian ini. ibu mendapatkan informasi tentang kebutuhan gizi balita dari penyuluhan yang diberikan puskesmas setiap pelaksanaan program posyandu .Informasi ini meningkatkan pengetahuan yang diiringi dengan perilaku baru dalam pemberian makanan bergizi bagi balita sehingga status gizi pun menjadi baik (Susilowati \& Himawati, 2017).

\section{SIMPULAN}

Berdasarkan analisa univariat diperoleh mayoritas pengetahuan ibu baik, mayoritas pendidikan ibu tinggi dan mayoritas status gizi balita baik, sedangkan hasil berdasarkan analisa bivariat dengan menggunakan uji chi-square menunjukkan bahwa ada hubungan pengetahuan dan pendidikan terhadap status gizi balita.

\section{SARAN}

Diharapkan bagi ibu untuk meningkatkan pengetahuan dengan selalu mengikuti penyuluhan-penyuluhan tentang kesehatan khususnya status gizi balita, begitu juga bagi tenaga kesehatan lebih meningkatkan lagi konseling terhadap keluarga, penyuluhanpenyuluhan kesehatan, serta meningkaykan pelayanan kesehatan.

\section{DAFTAR PUSTAKA}

Adriani, M., \& Wiratmadi, B. (2014). Gizi dan Kesehatan Balita Peranan Mikro Zinc pada Pertumbuhan Balita. Jakarta: Kencana Prenadamedia Group

Astuti, F. D., \& Sulistyowati, T. F. (2012). Hubungan Tingkat Pendidikan Ibu dan Tingkat Pendapatan Keluarga dengan Status Gizi Anak Prasekolah dan Sekolah Dasar di Kecamatan Godean. Kesmas, 7(1),15-20

Betz, C. L., Sowden, S., \& Linda, A. (2009). Buku Saku Keperawatan Pediatri Edisi 5. Jakarta: EGC

Burhani, P. A., Oenzil, F., \& Revilla, G. (2018). Hubungan Tingkat Pengetahuan Ibu dan Tingkat Ekonomi Keluarga Nelayan dengan Status Gizi Balita di Kelurahan Air Tawar Barat Kota Padang. Jurnal Kesehatan Andalas, 5(3), 515-521. http://jurnal.fk.unand.ac.id

Departemen Kesehatan RI. (2011). Keputusan Menteri Kesehatan Republic Indonesia. Nomor 1995/Menkes/SK/XII/2010 tentang Standar Antropometri Penilaian Status Gizi Anak. Direktorat Bina Gizi. Jakarta

Dinas Kesehatan Kota Pekanbaru. (2015). Profil Kesehatan Provinsi Riau

Herman, S. (2009). Review on The Problem Zinc Defficiency, Problem Prevention and Its Prospect. Media Penelitian dan Pengembangan Kesehatan, 75-83

Jannah, M., \& Maesaroh, S. (2014). Hubungan Tingkat Pendidikan Ibu dengan Status Gizi Balita di Posyandu Bangunsari Semin Gunung Kidul Tahun 2014. Jurnal Kebidanan Indonesia, 6(1). 42-52. DOI: https://doi.org/10.36419/jkebin.v6i1.100 
Kemenkes. (2015). Rencana Strategis Kementerian Kesehatan Tahun 2015-2019

Kurniawati, E. (2011). Hubungan Tingkat Pengetahuan Ibu tentang Gizi dengan Status Gizi Balita di Kelurahan Baledeno Kecamatan Purworejo Kabupaten Purworejo. Jurnal Ilmu Kesehatan, 3(2)

Lestari, P., \& Hati, F. S. (2016). Pengaruh Pemberian Stimulasi pada Perkembangan Anak Usia 12-36 The Influence of Stimulation in Children Aged 12-36 Months in Sedayu Regency, Bantul. Jurnal Ners Dan Kebidanan Indonesia, 4(1), 44-48. https://doi.org/http://dx.doi.org/10.21927/jnki

Lubis, C. (2004). Usaha Pelayanan Kesehatan Anak dalam Membina Keluarga Sejahtera. Medan

Meikawati, W., \& Wikana, H. (2008). Hubungan Karakterisitk Ibu dan Tingkat Ekonomi Sosial Keluarga terhadap Kasus Gizi Buruk pada Balita di Kelurahan Tandang Kecamatan Tembalang. Prosiding Seminar Nasional dan Internasional, 148-157. http://jurnal.unimus.ac.id

Merryana, A. (2012). Peran Gizi dalam Siklus Kehidupan. Jakarta: Kharisma Putra Utama

Morani, W. (2008). Hubungan Pengetahuan Ibu tentang Makanan Bergizi terhadap Status Gizi Balita di Kecamatan Kotanopan, Kabupaten Mandailing Natal. Medan. Universitas Sumatera Utara

Munawaroh, S. (2015). Pola Asuh Mempengaruhi Status Gizi Balita. Jurnal Keperawatan, 6(1), 44-50

Notoatmojo, S. (2010). Promosi Kesehatan Teori dan Ilmu Perilaku. Jakarta: Rineka Cipta

Padila, P., Andari, F. N., Harsismanto, J., Andri, J. (2019). Tumbuh Kembang Anak Usia Toddler Berbasis Research. Lubuklinggau: Asra

Padila, P., Andari, F, N., Andri, J. (2019). Hasil Skrining Perkembangan Anak Usia Toddler antara DDST dengan SDIDTK. Jurnal Keperawatan Silampari, 3(1), 244256. https://doi.org/https://doi.org/10.31539/jks.v3i1.809

Proverawati, A. (2009). Gizi untuk Kebidanan. Yogyakarta: Nuha Medika

Puspasari, N., \& Andriani, M. (2017). Hubungan Pengetahuan Ibu tentang Gizi dan Asupan Makan Balita dengan Status Gizi Balita (BB/U) Usia 12-24 Bulan. Open Acces: Amerta Nutr, 369-378. DOI : 10.2473/amnt.v1i4.2017.369-378

Ranityas, K., Era, R., \& Diyah, Y. (2016). Hubungan Tingkat Pendidikan Ibu dengan Status Gizi Balita di Puskesmas Pleret. Jurnal Kesehatan, 7(1)

Rahardjo, S., Wayanti, S., \& Wardani, N. E. K. (2019). Pengaruh Fungsi Manajemen Pelaksana Kegiatan SDITK terhadap Cakupan SDITK Balita \& Anak Prasekolah. Jurnal Pamator, 12(1). https://doi.org/http://dx.doi.org/10.21107/pmt.v12i1.5173http://repository.usu.ac.i $\mathrm{d} /$ handle/1 23456789/32433

Rakhmawati, N. Z., \& Panunggal, B. (2014). Hubungan Pengetahuan dan Sikap Ibu dengan Perilaku Pemberian Makanan Anak Usia 12-24 Bulan. Jurnal of Nutrition Collage, 3(1)

Soetjiningsih, S. (2014). Tumbuh Kembang Anak. Jakarta: EGC

Soetjiningsih, R. (2015). Tumbuh Kembang Anak. Jakarta: EGC

Sulistyawati, A. (2015). Deteksi Tumbuh Kembang Anak. Jakarta: Salemba Medika

Supariasa, S., Bakrie, B., \& Fajar, I. (2012). Penilaian Status Gizi. Jakarta: EGC

Susanti, R., Indriati, G., \& Utomo, W. (2014). Hubungan Pengetahuan Ibu tentang Gizi dengan Status Gizi Anak Usia 1-3 Tahun. Jom PSIK, 1(2), 1-7 
Susilowati, E., \& Himawati, A. (2017). Hubungan Tingkat Pengetahuan Ibu tentang Gizi Balita dengan Status Gizi Balita di Wilayah Kerja Puskesmas Gajah 1 Demak. Jurnal Kebidanan, 6(13), 21-25

Wati, S. P., \& Subagyo, A. (2018). Hubungan Tingkat Pendidikan, Pengetahuan Ibu dan Pendapatan Orangtua dengan Status Gizi Anak Balita Usia 1-5 Tahun di Desa Duwet Kecanatan Wonosari Kabupaten Klaten. Naskah Publikasi. Universitas Muhammadiyah Surakarta

WHO. (2015). Obesity: Preventing and Managing the Global Epidemic. Geneva Yuli, A. (2016). Cara Mudah Asah Otak Anak. Jakarta: Flashbook 